\title{
拡張パルス伝達関数の既約分解に基づく サンプル值制御系の解析と設計
}

\author{
杉 江 俊 治*・村 井 雅 彦**
}

\section{Analysis and Design of Sampled-Data Control Systems Based on Stable Factorizations of Modified Pulse Transfer Functions}

\author{
Toshiharu SugIE* and Masahiko MuRAI**
}

\begin{abstract}
This paper presents a new approach to analysis and design of multivariable sampled-data control systems. First, exploiting the modified pulse transfer function representation, we show that the factorization approach is useful to characterize all the admissible intersample output behavior in sampled-data control systems. Second, we give a solution to the $l_{2} / \mathcal{L}_{2}$-induced norm optimization problem, where continuous time behavior of sampled-data systems is taken into account. Then, we apply these results to the model-matching problem to show the validity of our method by simulation.
\end{abstract}

Key Words : sampled-data control system, modified pulse transfer function, stable factorization, intersample behavior, model-matching

\section{1.はじめに}

連続時間の制御対象をディジタル補償器を用いて制御 するサンプル值制御系に関して, 従来より多くの研究が なされている。このような制御系においては，単にサン プル点上のシステムの挙動だけでなくサンプル点の間の 疬答についても考慮すべきであると，従来より指摘され ており，このようなサンプル点間の応答を調べる手法と して，拡張パルス伝達関数を用いる方法がよく知られて いる ${ }^{1)}$. しかし, この方法は拡張 $z$ 変換の複雑さなどのた め, 統一的な見通しのよい理論展開が困難と考えられ, 設計法として積極的に用いられることは少なかった。

これに対して，近年，連続時間信号をべースとしたサ ンプル值制御系の解析や設計が活発に研究されてきてい $3^{2) \sim 11}$.たとえば, 連続時間信号の評価関数を用いたサン プル值系の LQR 問題2),3) や $\mathscr{H}_{2}$ 最適制御問題 ${ }^{11)}$, サンプ ル值系の $\mathscr{L}_{p}$ 安定性の証明5),10) や $\mathscr{L}_{2}$ induced ノルムの 計算法6),さらには $H_{\infty}$ タイプの最適制御問題( ) などが考

$*$ 京都大学工学部 宇治市五ケ庄

** (株) 東芝 総合研究所川崎市川崎区浮島町 4-1

* Faculty of Engineering, Kyoto University, Uji

** R \& D Center, Toshiba Corporation, Kawasaki (Received September 12, 1991)

(Revised January 27, 1992)
察されてきており，注目すべき結果が得られつつある。 また，関数空間の手法を用いてサンプル值系を解析する

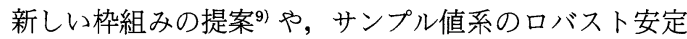
性の解析7),12) などもなされている。これらの結果はそれ ぞれ注目に值する優れたものであるが，その多くは，連 続信号と離散信号を混在させたまま，線形時変系として 系を取り扱っているので, 近年発展の著しい既約分解に 基づく代数的設計法の成果 ${ }^{13)}$ を利用することができな い.このため，たとえば，サンプル值制御系において実 現可能な目標值応答のクラスなども明確でない.

そこで本論文では，サンプル点間の応答を考慮にいれ ることができ，かつ線形時不変系としてサンプル值系を 扱えるという観点から, 拡張パルス伝達関数に着目し, この既約分解表現を用いてサンプル值系を解析すること を考える.そして,この結果, サンプル点間の目標值応答 を規定する伝達関数の実現可能なクラスなどが非常に 簡単な形で得られ，サンプル点間の応答を考慮した制御 系設計の見通しがよくなることを示す。さらに，ディジ タル補償器の最適設計の観点から, サンプル值系の出力 を連続時間信号として評価する $l_{2} / \mathscr{L}_{2}$-induced ノルム 最適化問題を考え, その一つの解法を与える. また, こ の結果をサンプル点間応答を考慮したモデルマッチング 問題に適用し，数値例によってこの手法の有効性を検討 
する。

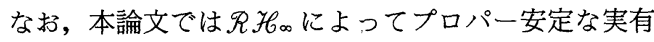
理行列の集合を表わす。また，読者は $\mathscr{R} \mathscr{H}_{\infty}$ 上の既約分 解 ${ }^{13)}$ に関する知識を有するものと仮定する.

\section{2 自由度サンプル値制御系}

\section{1 制御対象の記述}

Fig. 1 に示すようなプロパーな連続時間制御対象 $\tilde{P}(s)$, ディジタル補償器 $C[z]$ とサンプリング周期 $h$ の サンプラ \&およびホールド员からなるサンプル值制御系 を考える：ここで， $\tilde{u}(t), \tilde{y}(t)$ はそれぞれ連続時間の $p$ 次元制御対象入力, $q$ 次元制御対象出力を表わし, $u[k]$, $y[k], r[k]$ はそれぞれ離散時間の $p$ 次元制御入力, $q$ 次 元観測量, $q$ 次元目標值信号を表わす, $C[z]$ は $r[k]$ と $y[k]$ の情報から $u[k]$ を定める一般的な形式の 2 自由度 補償器である。サンプラ \&は連続時間信号から離散時間 信号へ変換するオペレータであり, $y=\& \tilde{y}$ は

$$
y[k]=\tilde{y}(k h)
$$

を意味し，ホールド $\mathscr{H}$ は逆に離散時間信号を連続時間信 号に変換するオペレータであり, $\tilde{u}=\mathscr{H} u$ は

$$
\tilde{u}(t)=H(t) u[k], \quad k h \leq t<(k+1) h
$$

を意味するものとする。ここで, $H(t)$ は周期 $h$ の有界な 周期関数行列であり, $H(t)=I$ (単位行列) のときには, 通常の 0 次ホールドを表わす.

$u[k]$ から $y[k] へ$ \& $\widetilde{P}(s) \mathscr{H}$ のパルス伝達関数を $P[z]$ とし, サンプル点間の応答を知るために, $u[k]$ から 時刻 $t=(k+m) h(0 \leq m<1)$ の制御対象出力 $y[k, m]$ $:=\tilde{y}(k h+m h) \sim の \tilde{P}(s) \mathscr{H}$ の拡張パルス伝達関数を $P[z, m]$ とする.

さて, 制御対象のパルス伝達関数と拡張パルス伝達関 数の状態空間表現を求めておく。いま $\tilde{P}(s)$ の状態空間 表現が,

$$
\left\{\begin{array}{l}
\dot{\tilde{x}}(t)=\tilde{A} \tilde{x}(t)+\tilde{B} \tilde{u}(t) \\
\tilde{y}(t)=\tilde{C} \tilde{x}(t)+\tilde{D} \tilde{u}(t)
\end{array}\right.
$$

と表わされるものとする.ただし, $\tilde{A} \in \mathscr{R}^{n \times n}, \tilde{B} \in \mathscr{R}^{n \times p}$, $\tilde{C} \in R^{q \times n}, \tilde{D} \in R^{q \times p}$ である.このとき, $x[k]=\tilde{x}(k h) を$ 状態べクトル, $u[k]$ を入力, $y[k]$ と $y[k, m]$ を出力とし て，離散化された制御対象を記述すれば，

$$
x[k+1]=A x[k]+B u[k]
$$

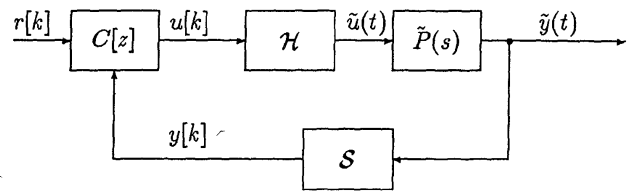

Fig. 1 2 D. O. F. Sampled-data control system

$$
\begin{aligned}
& y[k]=C x[k]+D u[k] \\
& y[k, m]=C(m) x[k]+D(m) u[k]
\end{aligned}
$$

となる。ただし，

$$
\left\{\begin{array}{l}
A:=e^{\tilde{A} h}, B:=\int_{0}^{h} e^{\tilde{A}(h-\tau)} \tilde{B} H(\tau) d \tau, \\
C:=\tilde{C}, D:=\tilde{D} H(0), \\
C(m):=\tilde{C} e^{\tilde{A} m h} \\
D(m):=\int_{0}^{m h} \tilde{C} e^{\tilde{A}(m h-\tau)} \tilde{B} H(\tau) d \tau+\tilde{D} H(m h)
\end{array}\right.
$$

である.したがって,パルス伝達関数 $P[z]$ の状態空間表 現は (4), (5) 式で, 拡張パルス伝達関数 $P[z, m]$ のそれ は (4)，(6)式で与えられ，それぞれの伝達関数の値は

$$
\begin{aligned}
& P[z]=C(z I-A)^{-1} B+D \\
& P[z, m]=C(m)(z I-A)^{-1} B+D(m)
\end{aligned}
$$

によって計算できる。ここで，明らかに

$$
P[z]=P[z, 0], C=C(0), D=D(0)
$$

が成立している。

\section{2 拡張パルス伝達関数の既約分解}

本論文ではつぎの仮定をおく。

[仮定 1] $(A, B)$ は可安定， $(C, A)$ は可検出.

この仮定はそれほど強くない。たとえば，通常の 0 次 ホールド（すなわち $H(t)=I ）$ の場合には，もとの連続 系の $(\tilde{C}, \tilde{A}, \tilde{B})$ が可検出・可安定であれば, ほとんどす心゙ てのサンプル周期 $h$ に対して, 上記の仮定が成立するこ とはよく知られている11.

このとき，拡張パルス伝達関数の既約分解に関してつ ぎの命題が成り立つ。

[命題 1] 仮定 1 の下で， $P[z]$ の $\mathscr{R} \mathscr{H}_{\infty}$ 上の右既約分 解を $N[z] M[z]^{-1}$ とするとき, $P[z, m]=N[z$, $m] M[z]^{-1}$ が任意の $m \in[0,1)$ に対して右既約分解とな るような $N[z, m] \in \mathscr{R} \mathscr{H}_{\infty}$ が存在する.

（証明） $(A, B)$ が可安定なので, $A_{K}:=A-B K$ を安 定行列（すべての固有値の絶対值が 1 より小さい）とす る定数行列 $K$ が存在する。これを用いて, Nettらの方 法 ${ }^{14)}$ に従い,

$$
\begin{aligned}
N_{0}[z]=D+ & (C-D K)\left(z I-A_{K}\right)^{-1} B \\
N_{0}[z, m]= & D(m) \\
& +(C(m)-D(m) K)\left(z I-A_{K}\right)^{-1} B \\
M_{0}[z]=I- & K\left(z I-A_{K}\right)^{-1} B
\end{aligned}
$$

と選べば, $N_{0}[z], N[z, m], M[z]$ が $\mathscr{R} \mathscr{H}_{\infty}$ に属し, $P[z]$ $=N_{0}[z] M_{0}[z]^{-1}$ および $P[z, m]=N_{0}[z, m] M_{0}[z]^{-1}$ が成立 することは容易に確認できる。さらに，仮定より $(C, A)$ は可検出であり，このときには任意の $m$ に対して $(C(m), A)$ も自動的に可検出となる (付録命題 $\mathrm{A}$ 参照) ので，上記の分解は共に右既約分解となっている ${ }^{13)}$. 
さて, $N[z] M[z]^{-1}$ を $P[z]$ の任意の右既約分解とする とき,

$$
N[z]=N_{0}[z] U[z], M[z]=M_{0}[z] U[z]
$$

を満たすユニモジュラ行列 $U[z]$ が存在するので, $P[z$, $m]=\left(N_{0}[z, m] U[z]\right)\left(M_{0}[z] U[z]\right)^{-1}$ と右既約分解すれ ば，命題の成立することがわかる.

この命題は「拡張パルス伝達関数 $P[z, m]$ の右既約分 解を適当に選べば, $m$ に依存するのは分子行列 $N[z, m]$ のみであり, 分母行列 $M[z]$ は $m$ に依存せず，しかも $P[z]$ の分母行列に一致させることができる」ことを明ら かにしている.この点が以下の解析に非常に重要となる.

（注）なお，左既約分解に関してはこのことは一般に

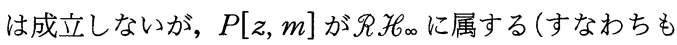
との連続系 $\tilde{P}(s)$ がプロパー安定)か，あるいはスカラー 系であるときに成立することは容易に確認できる。

\section{3 実現可能な目標值応答のクラス}

この節では，既約分解に基づいて，すべての安定化補 償器のパラメータ表現を与え, 2 自由度サンプル值系に おいて実現可能な目標值応答のクラスなどを明らかにす る.

まず，内部安定性を定義するため, Fig. 1 の制御系にお いて, $u[k] に d_{1}[k], y[k] に d_{2}[k]$ なる外部信号を加え ると, 制御系は

$$
\begin{aligned}
& {\left[\begin{array}{c}
y[z, m] \\
y[z]
\end{array}\right]=\left[\begin{array}{c}
P[z, m] \\
P[z]
\end{array}\right]\left(u[z]+d_{1}[z]\right)} \\
& u[z]=C[z]\left[\begin{array}{c}
r[z] \\
y[z]+d_{2}[z]
\end{array}\right]
\end{aligned}
$$

と書ける。後の表記の便宜のため $C[z] を r[k]$ と $y[k]$ の次元数に応じて $C[z]=:\left[C_{1}[z],-C_{2}[z]\right]$ と分割して おく.このとき, $\left(r[k], d_{1}[k], d_{2}[k]\right)$ から $(u[k], y[k]$, $y[k, m])$ への六つのパルス伝達関数がすべて $\mathscr{R} H_{\infty}$ に属 するならば，制御系は内部安定という。

いま， $P[z]$ の $\mathfrak{H}_{\infty}$ 上の左右既約分解および Bezout 等式の解を

$$
\begin{aligned}
& P[z]=N[z] M[z]^{-1}=\tilde{M}[z]^{-1} \tilde{N}[z] \\
& \tilde{X}[z] N[z]+\tilde{Y}[z] M[z]=I
\end{aligned}
$$

とする.このとき，命題 1 より，

$$
\left[\begin{array}{c}
P[z, m] \\
P[z]
\end{array}\right]=\left[\begin{array}{c}
N[z, m] \\
N[z]
\end{array}\right] M^{-1}[z]
$$

となる。(19)式において $N[z]$ と $M[z]$ が右既約である ことは, この制御対象が $u[k]$ から可安定, $y[k]$ から可検 出であることを示しているので，サンプル点上だけをみ た $P[z]$ を内部安定化しておけば十分であることが予想 され，実際つぎの結果を得る。

[定理 1] Fig. 1 のサンプル值系を内部安定にするす べての補償器は，次式のようにパラメー夕表現できる。

$$
\begin{aligned}
C[z]= & {\left[C_{1}[z],-C_{2}[z]\right] } \\
= & (\tilde{Y}[z]-Q[z] \tilde{N}[z])^{-1}[K[z], \\
& -(\tilde{X}[z]+Q[z] \tilde{M}[z])]
\end{aligned}
$$

ここで, $K[z], Q[z] \in \mathscr{R} H_{\infty}$ は適当なサイズの自由パラ メータである。

(証明) $\quad\left(r[k], d_{1}[k], d_{2}[k]\right)$ から $(u[k], y[k]) へ の$ 六 つのパルス伝達関数をプロパー安定にするすべての補償 器が (20)式のパラメータ表現で与えられることはよく知 られている ${ }^{13)}$. よって, この補償器が $\left(r[k], d_{1}[k], d_{2}[k]\right)$ から $y[k, m]$ へのうの伝達関数をプロパー安定にする ことを示せば十分であるが，これらは後の $(21) 〜(23)$ 式 に示すようにR $\mathscr{H}_{\infty}$ に属する。

$\left(r[k], d_{1}[k], d_{2}[k]\right)$ から $y[k, m]$ への三つの拡張パル ス伝達関数をそれぞれ $G_{y r}[z, m], G_{y d_{1}}[z, m], G_{y d_{2}}[z$, $m]$ とする.このとき, 安定化補償器によって実現できる これらの伝達関数のクラスは(15), (16), (19), (20)式よ りつぎのように表現できる.

$$
\begin{aligned}
G_{y r}[z, m] & =P[z, m]\left(I+C_{2}[z] P[z]\right)^{-1} C_{1}[z] \\
& =N[z, m] K[z] \\
G_{y d_{1}}[z, m] & =P[z, m]\left(I+C_{2}[z] P[z]\right)^{-1} \\
& =N[z, m](\tilde{Y}[z]-Q[z] \tilde{N}[z]) \\
G_{y d_{2}}[z, m] & =-P[z, m]\left(I+C_{2}[z] P[z]\right)^{-1} C_{2}[z] \\
& =-N[z, m](\tilde{X}[z]+Q[z] \tilde{M}[z])
\end{aligned}
$$

(21) 式はサンプル点間 $y[k, m]$ への実現可能な目標值応 答のクラスが $N[z, m]$ (すなわち $P[z, m]$ の分子行列) と自由パラメータ $K[z]$ の積としてコンパクトに表現で きることを示している。ここで $m=0$ と打けば $G_{y r}[z]$ $=N[z] K[z]$ となり,これはよく知られた離散系のクラス 表現にほかならない。この意味では(21) 式は従来結果を サンプル点間応答へ拡張したものといえる，(22)，(23） 式も同様である。これらの式において重要な点は (i ) $m$ に依存するのが $N[z, m]$ のみであり, 他は $P[z]$ のデー タだけから計算できること，および，容易に確認できる ことであるが(ii)通常の離散系 $P[z]$ に対して $G_{y r}[z]$, $G_{y d_{1}}[z], G_{y d_{2}}[z]$ を計算して $N[z]$ のかわりに $N[z, m]$ を代入するだけでこれらの式が得られる点にある。

このように，拡張パルス伝達関数の既約分解を用いれ ば，サンプル点間応答の実現可能なクラスは非常に簡潔 な形で表現されるため，サンプル点間の応答を考慮した 制御系の設計が見通しょく行えることが期待できる。ま た, 目標値応答は $K \in R \mathscr{H} \mathscr{H}_{\infty} て ゙$, ほかのフィードバック特

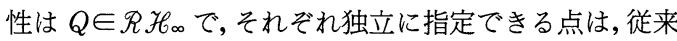
の連続時間系（あるいは離散時間系）の場合と同様であ り，2 自由度補償器を用いることはサンプル值系の設計 に際しても有用である。 


\section{3. $l_{2} / \mathscr{L}_{2}$-induced ノルム最適化問題}

前章では, サンプル值制御系のすべての安定化補償器 や実現可能な目標値応答のクラスを明らかにした。本章 では, サンプル点間の応答を考慮した最適設計の観点か ら, 具体的に一つの安定化補償器を定める方法を考える. すなわち, サンプル值系への離散入力を $l_{2}$ ノルム, 連続 出力を $\mathscr{L}_{2}$ ノルムではかり, その $l_{2} / \mathscr{L}_{2}$-induced ノルム を最適化する問題を考え，その一つの解法を与える. そ して, この方法をサンプル点間の応答を考慮したモデル マッチング問題に適用し，その有効性をシミュレーショ ンによって検討する。

\section{$3.1 l_{2} / \mathscr{L}_{2}$-induced ノルムの計算法}

まず, 最適化補償器を求める準備として, Fig. 2 に示 す連続時間系とホールドから成る $\tilde{P}(s) \mathscr{H}$ の $l_{2} / \mathscr{L}_{2^{-}}$ induced ノルム, すなわち,

$$
\|\tilde{P}(s) \mathscr{H}\|_{l_{2} / \mathscr{L}_{2}}=\sup _{u \in l_{2}} \frac{\|\tilde{y}(t)\|_{2}}{\|u[k]\|_{2}}
$$

を求める方法について述べる.

$\tilde{P} \mathscr{H}$ の拡張パルス伝達関数 $P[z, m]$ の状態空間表現は 2 章の議論より

$$
\left\{\begin{array}{l}
x[k+1]=A x[k]+B u[k] \\
y[k, m]=C(m) x[k]+D(m) u[k]
\end{array}\right.
$$

と表わされることに注意する。いま, $y[k, m]=\tilde{y}(k h$ $+m h)$ であることから

$$
\begin{aligned}
\|\tilde{y}(t)\|_{2}^{2} & =\int_{0}^{\infty} \tilde{y}^{T}(t) \tilde{y}(t) d t \\
& =\sum_{k=0}^{\infty} \int_{0}^{1} y^{T}[k, m] y[k, m] h d m \\
& =\sum_{k=0}^{\infty}\left[x^{T}[k] u^{T}[k]\right] W\left[\begin{array}{l}
x[k] \\
u[k]
\end{array}\right]
\end{aligned}
$$

が成り立つ.ここで，Wは

$$
\begin{aligned}
& W:=\int_{0}^{1} E(m)^{T} E(m) h d m \\
& E(m):=[C(m), D(m)]
\end{aligned}
$$

で定義されるものである.この $W$ を，

$$
\left[\begin{array}{l}
\widehat{C}^{T} \\
\widehat{D}^{T}
\end{array}\right]\left[\begin{array}{ll}
\widehat{C} & \widehat{D}
\end{array}\right]=W
$$

と分解する.ただし， $\widehat{C} \in \mathscr{R}^{(n+p) \times n}, \hat{D} \in \mathscr{R}^{(n+p) \times p}$ である (ここで, $n$ は状態 $x[k]$ の次元, $p$ は入力 $u[k]$ の次元で あったことに注意されたい). そして, 離散時間の出力 $\widehat{y}[k] \in \mathscr{R}^{(n+p)}$ を

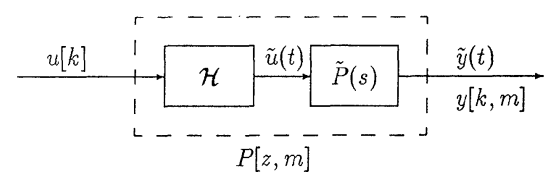

Fig. 2 Continuous time plant with hold

$$
\widehat{y}[k]=\widehat{C} x[k]+\hat{D} u[k]
$$

によって定義すれば，明らかに

$$
\|\widehat{y}[k]\|_{2}^{2}=\sum_{k=0}^{\infty} \widehat{y}^{T}[k] \widehat{y}[k]=\|\widetilde{y}(t)\|_{2}^{2}
$$

が成立する。よって，

$$
\left\{\begin{array}{l}
x[k+1]=A x[k]+B u[k] \\
\widehat{y}[k]=\widehat{C} x[k]+\widehat{D} u[k]
\end{array}\right.
$$

なる状態空間表現で記述される離散時間系 $\hat{P}[z]$ を考え ると,つぎの定理を得る。

[定理 2] (25)式で表現される系 $\tilde{P}(s) \mathscr{H} の l_{2} / \mathscr{L}_{2^{-}}$ induced ノルムは, (31) 式で表現される離散系の $\mathscr{H}_{\infty}$ ノ ルム $\|\hat{P}[z]\|_{\infty}$ に等しい.

（証明）（30)式と $\mathscr{H}_{\infty}$ ノルムの定義から

$$
\|\hat{P}[z]\|_{\infty}=\sup _{u \in \iota_{2}} \frac{\|\hat{y}[k]\|_{2}}{\|u[k]\|_{2}}=\sup _{u \in \tau_{2}} \frac{\|\tilde{y}(t)\|_{2}}{\|u[k]\|_{2}}
$$

が成り立つことより明らか.

離散時間系の $\mathscr{H}_{\infty}$ ノルムの計算法は確立されているの で,いったん, inducedノルムの等価な離散系を上記手順 により求めれば, $l_{2} / \mathscr{L}_{2}$-induced ノルムが計算できるこ とになる.

Chen $ら^{6)}$ は同様の問題をオペレータ理論を用いて考 察しているが, inducedノルムの計算法と考え方はかな り複雑である.これに対して, 本論文の方法はきわめて 簡単である.また, 本手法では, induced ノルム等価な離 散系において,もとのサンプル值系の状態量 $x[k]$ が保 存されている.この点が次節の最適化問題への応用に際 して非常に重要である。

なお,この定理 2 に関して, 筆者らとは独立に早川ら ${ }^{15)}$ が本質的に同じ結果を得ている.

\section{$3.2 l_{2} / \mathscr{L}_{2}$-induced ノルム最適化}

つぎに, 通常の $\mathscr{H}_{\infty}$ 制御問題と同様に一般的な定式化 を行うために, Fig. 3 に示す一般化制御系を考える.ここ で, $r[k], u[k], y[k]$ は適当な次元の離散時間信号で, そ れぞれ外部入力, 制御入力, 観測量を表わし, $\tilde{e}(t)$ は連 続時間の制御量を表わす。この制御系の伝達関数表現を

$$
\begin{aligned}
& {\left[\begin{array}{c}
e[z, m] \\
y[z]
\end{array}\right]=\left[\begin{array}{cc}
G_{11}[z, m] & G_{12}[z, m] \\
G_{21}[z] & G_{22}[z]
\end{array}\right]\left[\begin{array}{c}
r[z] \\
u[z]
\end{array}\right]} \\
& u[z]=C[z] y[z]
\end{aligned}
$$

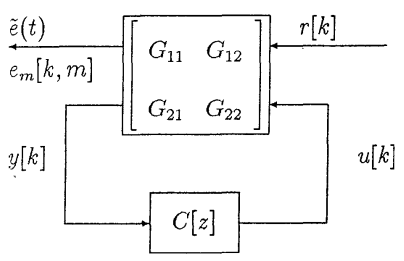

Fig. 3 Generalized Sampled-data feedback system 
であるとする。（33)式は一般化制御対象を(34) 式は補償 器を表わす。ここで $e[z, m]$ は $e[k, m]:=\tilde{e}(k h+m h)$ の $z$ 変換であり, $G_{11}[z, m], G_{12}[z, m]$ は拡張パルス伝 達関数である.このとき, $l_{2} / \mathscr{L}_{2}$-induced ノルム最適化問 題とは, 制御系を内部安定にする補償器のなかから

$$
J=\sup _{r \in l_{2}} \frac{\|\tilde{e}(t)\|_{2}}{\|r[k]\|_{2}}
$$

なる評価関数を最小にする最適解 $C[z]$ を求める問題で ある。

$$
\begin{aligned}
& \text { さて, (33) 式の状態空間表現が, } \\
& \left\{\begin{array}{l}
x[k+1]=A x[k]+B_{1} r[k]+B_{2} u[k] \\
e[k, m]=C_{1}(m) x[k]+D_{11}(m) r[k]+D_{12}(m) u[k] \\
y[k]=C_{2} x[k]+D_{21} r[k]+D_{22} u[k]
\end{array}\right.
\end{aligned}
$$

で与えられるものとし，先と全く同様にして，

$$
\begin{aligned}
& W_{G P}=\int_{0}^{1} E_{G}(m)^{T} E_{G}(m) h d m \\
& E_{G}(m):=\left[C_{1}(m), D_{11}(m), D_{12}(m)\right]
\end{aligned}
$$

なる行列を考え，この分解形を，

$$
\left[\begin{array}{c}
\widehat{C}_{1}^{T} \\
\widehat{D}_{11}^{T} \\
\hat{D}_{12}^{T}
\end{array}\right]\left[\begin{array}{lll}
\widehat{C}_{1} & \widehat{D}_{11} & \hat{D}_{12}
\end{array}\right]=W_{G P}
$$

とする. 各行列のサイズは先と同様適当に選ばれている とする。新たな離散時間制御量 $\hat{e}[k]$ を

$$
\hat{e}[k]=\widehat{C}_{1} x[k]+\widehat{D}_{11} r[k]+\widehat{D}_{12} u[k]
$$

と定めれば，明らかに

$$
\|\tilde{e}(t)\|_{2}=\|\hat{e}[k]\|_{2}
$$

を得る。ここで,

$$
\left\{\begin{array}{l}
x[k+1]=A x[k]+B_{1} r[k]+B_{2} u[k] \\
\hat{e}[k]=\widehat{C}_{1} x[k]+\widehat{D}_{11} r[k]+\widehat{D}_{12} u[k] \\
y[k]=C_{2} x[k]+D_{21} r[k]+D_{22} u[k]
\end{array}\right.
$$

で与えられる離散時間の一般化制御対象 $\hat{G}[z]$ と(34)式 の補償器 $C[z]$ からなる Fig. 4 の離散時間制御系を考 え, $r[k]$ から $\hat{e}[k] へ の l_{2}$-induced ノルムを最小にする 安定化補償器 $C[z]$ を $H_{\infty}$ 最適解とよぶことにすれば,つ ぎの定理を得る。

[定理 3] Fig. 3のサンプル值制御系における $l_{2} / \mathscr{L}_{2^{-}}$ induced ノルムの最適化問題の解は, Fig. 4 の離散時間

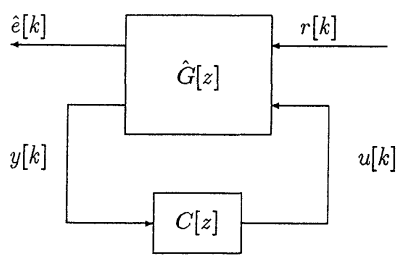

Fig. 4 Equivalent discrete-time system
系における $\mathscr{H}_{\infty}$ 最適解に等しい。

（証明）上記の議論より明らか.

離散時間系の $\mathscr{H}_{\infty}$ 制御問題の解法はいくつかすでに提 案されているので, いったん，(38)式を満たす $\widehat{C}_{1}$ などの 行列を求めて, (41)式の系を得れば, あとは, これらの 方法を利用して最適解を求めればよいことになる. Chen $ら^{6)}$ も同様の問題を考察しているが，その解法は概念的 なレベルにとどまっており，本報告のように具体的な手 順を与えているとはいえない.

\section{3 モデルマッチング問題への適用}

所期の目標值応答を得るための制御系設計問題の一つ にモデルマッチング問題がある．しかし，サンプル值制 御系においては, 目標値応答を規範モデルの応答に完全 に一致させることは, 一般に不可能である。そこで, $l_{2} / \mathscr{L}_{2}$-induced ノルム最適化の手法を応用して, サンプ ル点において規範モデルの応答と完全には一致しないか もしれないが，サンプル点間の応答を考慮にいれてモデ ルの応答と最も近くなるような補償器の一設計法を考え る.

2 章で述べた制御系を考えると, 目標值 $r[k]$ から出 力 $y[k, m]$ への拡張パルス伝達行列は (21) 式の $G_{y r}[z$, $m]=N[z, m] K[z]$ で与えられる.いま, 規範モデルを $\tilde{G}_{M}(s)$ とし, これにホールド $\mathscr{H}$ を加えた $\widetilde{G}_{M}(s) \mathscr{H}$ の拡張 パルス伝達関数を $G_{M}[z, m]$ とすると, 問題は $G_{M}[z, m]$ と $N[z, m] K[z]$ の差がなんらかの意味で最も小さくな るような $K[z]$ を見つけることとなる. 両者の目標值応 答の差を出力とする Fig. 5 の系を考えると, この系の入 力は離散時間であり出力は連続時間なので, $l_{2} / \mathscr{L}_{2}-$ induced ノルムを最小にする問題を考えれば, サンプル 点間の応答をも考慮したモデルマッチング問題を解くこ とになる。

この問題は Fig. 3 の一般化制御系において,

$$
\left[\begin{array}{cc}
G_{11}[z, m] & G_{12}[z, m] \\
G_{21}[z] & G_{22}[z]
\end{array}\right]=\left[\begin{array}{cc}
G_{M}[z, m] & -N[z, m] \\
I & 0
\end{array}\right]
$$

$$
C[z]=K[z]
$$

と選ぶことに対応しているので, 3.2 節の手順に従って, 離散時間系の $\mathfrak{H}_{\infty}$ 問題に帰着させて解くことができる.

$K[z]$ が定まれば，あとは任意の $Q[z] \in \mathscr{R} \mathscr{H}_{\infty}$ を選び

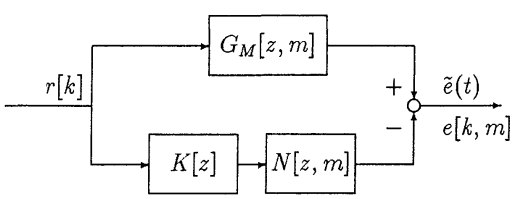

Fig. 5 Model-matching problem 
(20)式から $C[z]$ を計算すれば設計がおわる.

$$
\text { シミュレーション例 }
$$

次式で与えられる連続時間の制御対象をサンプル周期 $0.1[\mathrm{sec}]$ で制御することを考える.

$$
\tilde{P}(s)=\frac{1}{s-1}
$$

いま規範モデルとして，

$$
\widetilde{G}_{M}(s)=\frac{10}{s+10}
$$

を選び，これに0次ホールドを用いた場合のモデルマッ チング問題を考える.上記手順に従って計算するとつぎ の解を得る。

$$
K[z]=\frac{6.2113 z^{2}-0.0960 z}{z^{2}-0.3504 z-0.0064}
$$

ただし離散時間 $\mathscr{H}_{\infty}$ 最適制御問題を解くにあたっては, Kondo ら ${ }^{16)}$ の計算アルゴリズムを用いた.このときの規 範モデルと実際の制御対象のステップ応答をそれぞれ破 線および実線でFig. 6 に示す.

一方, サンプル点間を考慮せず, 従来のように制御系 を完全に離散系としてモデルマッチングした場合, 得ら れる解は,

$$
K[z]=\frac{6.0104 z}{z-0.3679}
$$

となる.両者の比較のためステップ応答における規範モ デル出力との誤差を Fig. 7 に示す. 実線が提案手法を用 いた場合, 破線が従来法の場合を示している。ここで提 案したモデルマッチング問題の解を用いた場合, サンプ

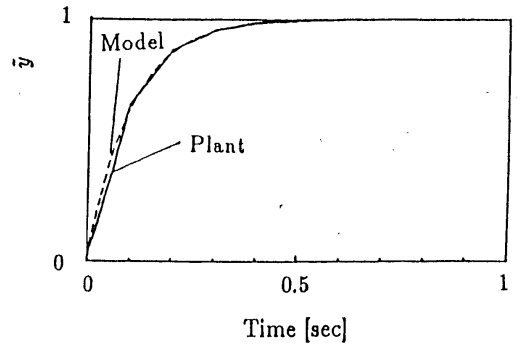

Fig. 6 Step response (propsed method)

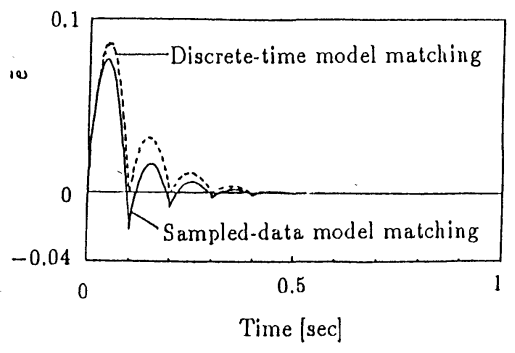

Fig. 7 Step response error
ル点では規範モデルの出力と一致していないが, サンプ ル点間全体でモデルの出力に近い応答を示していること がわかる、これに対して離散時間系のモデルマッチング 問題の解を用いると, サンプル点ではモデルの出力と完 全に一致しているが，サンプル点間においてはモデルの 応答との差が大きくなっている。

以上のことより，提案した設計法はサンプル值制御系 の一つの設計法として有効であると思われ, $l_{2} / \mathscr{L}_{2}$ induced ノルム最適化問題の有用性の一端を示したもの と考えられる。

\section{4.おわりに}

本論文では, 拡張パルス伝達関数の既約分解に着目し, サンプル点間の応答を考慮した 2 自由度サンプル值制御 系の解析・設計問題について考察した. その結果，サン プル值系においても既約分解に基づく代数的手法が活用 でき，たとえば，サンプル点間の目標值応答を規定する 伝達関数の実現可能なクラスなどが，従来の離散時間系 の自然な拡張として, 非常に簡潔な形で得られることを 明らかにした。さらに, ディジタル補償器の最適設計の 観点から, サンプル值制御系の出力を連続時間信号とし て評価する $l_{2} / \mathscr{L}_{2}$-induced ノルム最適化問題を考察し， その一つの解法を与えた。 そして，この結果をサンプル 点間応答を考慮したモデルマッチング問題に適用し，シ ミュレーションによりこの手法の有効性を検証した。

命題 $\mathrm{A}$ の証明を含め多くの重要な点に関して貴重な 助言をいただいた萩原朋道助教授，および日頃ご指導い ただく吉川恒夫教授に深く感謝します。

\section{考文 献}

1）美多，原，近藤：基礎ディジタル制御，コロナ社（1988）

2) A. H. Levis, R. A. Schlueter and M. Athans: On the Behaviour of Optimal Linear Sampled-Data Regulators, Int. J. Control, 13-2, 343/361 (1971)

3) R. Kondo and K. Furuta: Sampled-Data Optimal Control of Continuous Systems for Quadratic Criterion Function Taking Account of Delayed Control Action, Int. J. Control, 41-4, 1051/1060 (1985)

4) S. Urikura and A. Nagata: Ripple-Free Deadbeat Control for Sampled-Data Systems, IEEE Trans. Automatic Control, AC-32-6, 474/482 (1987)

5) B. A. Francis and T. T. Georgiou: Stability Theory for Linear Time-Invariant Plants with Periodic Digital Controllers, IEEE Trans., AC-33-9, 821/832 (1988)

6) T. Chen and B.A. Francis: On the $\mathscr{L}_{2}$-induced Norm of a Sampled-Data System, Systems \& Control Letters, 15-3, 211/219 (1990)

7）萩原, 藤村, 荒木 : サンプル值制御系のロバスト安定性, 第 19 回制御理論シンポジウム資料, 237/240（1990）

8) S. Hara and P. T. Kabamba: Worst Case Analysis and Design of Sampled-Data Control Systems, Proc. 29th IEEE CDC, Honolulu, 202/203 (1990)

9) Y. Yamamoto: New Approach to Sampled-Data Con- 
trol Systems - A Function Space Method, Proc. 29th IEEE CDC, Honolulu, 1882/1887 (1990)

10) T. Chen and B. A. Francis: Input-Output Stability of Sampled-Data Systems, IEEE Trans., AC-36-1, 50/58 (1991)

11) T. Chen and B. A. Francis : $\mathscr{H}_{2}-$ Optimal Sampled-Data Control, IEEE Trans., AC-36-4, 387/397 (1991)

12）原, 中島, Kabamba：サンプル值制御系のロバスト安定 化，第 13 回 Dynamical System Theory シンポジウム資 料, 115/120 (1991)

13）前田, 杉江：アドバンスト制御のためのシステム制御理 論, 朝倉書店 (1990)

14) C. N. Nett, C. A. Jacobson and M. J. Balas: A Connection between State-Space and Doubly Coprime Fractional Representations, IEEE Trans., AC-29-9, 831/832 (1984)

15）早川, 天野, 藤井：サンプル値系と induced ノルム等価な 離散時間系, 第 30 回 SICE 学術講演会予稿集, $63 / 64$ (1991)

16) R. Kondo, S. Hara and T. Itou: Characterization of Discrete-Time $H_{\infty}$ Controllers via Bilinear Transformation, Proc. 29th IEEE CDC, Honolulu, 1763/1768 (1990)

\section{《付 録》}

[命題 $\mathrm{A}] A, C(m)$ が( 7$)$ 式で定義されているとき, $(C, A)$ が可検出 (または可観測)であることと $(C(m), A)$ が任意の $m \in[0,1)$ に対して可検出 (または可観測) であ ることは等価である。

(証明) $A_{m}:=e^{\tilde{A}^{m h}}$ と扔くと, $C(m)$ と $A$ の定義よ り, $C(m)=C A_{m}$ かつ $A_{m} A=A A_{m}$ となる。また，任意 の $m$ に対して $\operatorname{det} A_{m} \neq 0$ である.これより, 任意の複素 数 $s$ に対して

$$
\begin{aligned}
\operatorname{rank}\left[\begin{array}{c}
s I-A \\
C(m)
\end{array}\right] & =\operatorname{rank}\left[\begin{array}{cc}
A_{m}^{-1} & 0 \\
0 & I
\end{array}\right]\left[\begin{array}{c}
s I-A \\
C
\end{array}\right] A_{m} \\
& =\operatorname{rank}\left[\begin{array}{c}
s I-A \\
C
\end{array}\right]
\end{aligned}
$$

が成立する。 $(C, A)$ が可検出のときは上式右辺は任意の $s \in C_{+}$（複素閉右半面）に対して列フルランクとなり, これは左辺より $(C(m), A)$ が可検出であることを意味 する。逆も同栐。

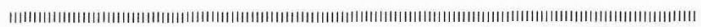

\section{[著 者 紹 介]}

\section{杉 江 俊 治（正会員）}

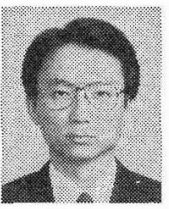

1978 年, 京都大学大学院修士課程 (精密 工学専攻) 修了. 84 年同博士課程研究指導 認定退学.この間 78 年より 80 年まで日本 電信電話公社勤務. 84 年大阪府立大学工学 部助手. 88 年京都大学工学部助教授となり 現在に至る、ロバスト制御, ロボット工学 の研究に従事. 日本ロボット学会, システ ム制御情報学会などの会員.（工学博士）

\section{村 井 雅 彦 (正会員)}

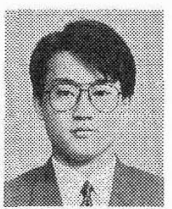

1989 年, 京都大学工学部精密工学科卒 業. 1991 年同大学大学院修士課程修了. 同 年(株) 東芝入社, 現在に至る. 総合研究所 エネルギー機器研究所にてシステム制御技 術を応用したプロセス制御系の開発に従 事. システム制御情報学会の会員. 